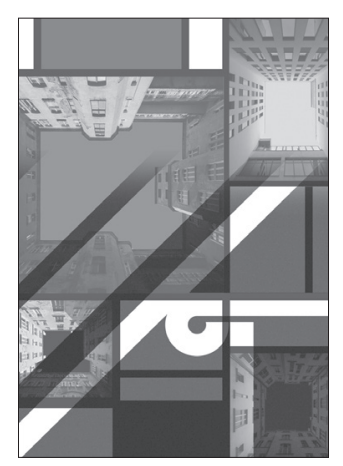

\title{
Karolina Jaklewicz*
}

\section{Lyonel Feininger - przestrzenie równoległe}

\author{
Lyonel Feininger-parallel spaces
}

\section{Wprowadzenie}

Rok 1919, Weimar. To tu rozpoczął swoją działalność Bauhaus, uczelnia artystyczno-rzemieślnicza powstała z połączenia Akademii Sztuk Pięknych i Szkoły Rzemiosł Artystycznych. Rok 2019, Wrocław. Na Wydziale Architektury Politechniki Wrocławskiej, w Zakładzie Rysunku, Malarstwa i Rzeźby rozpoczynamy obchody upamiętniające setną rocznicę powstania Bauhausu, jednej z najważniejszych i najbardziej wpływowych uczelni XX w. Nie budujemy niemych pomników, chcemy wrócić do idei bauhausowskich z perspektywy naszego czasu i miejsca, chcemy zaangażować studentki i studentów do wspólnych działań. Finałem całorocznego projektu jest wysta$\mathrm{wa}^{1}$ oraz konferencja naukowa.

W czasach budowania nowego ładu społecznego Bauhaus chciał tworzyć przestrzeń odpowiednią dla funkcjonowania nowoczesnego człowieka. Był rewolucyjny, zapalił się do fundamentalnych zmian i wiedział, że ma rację. Andrzej Turowski w manifeście artystyczno-politycznym Sztuka, która wznieca niepokój podkreśla szczególny związek awangardy z polityką. Jeśli rewolucyjne aspiracje

* ORCID: 0000-0003-4119-0720. Wydział Architektury Politechniki Wrocławskiej / Faculty of Architecture, Wrocław University of Science and Technology, e-mail: karolina.jaklewicz@pwr.edu.pl

1 Wystawa z cyklu „Przestrzeń architektury/przestrzeń sztuki - After Bauhaus" prezentowana była w Muzeum Architektury we Wrocławiu w dniach 16.01-23.02.2020. Pokazano prace wykładowczyń i wykładowców (H. Bujak, E. Górska, K. Jaklewicz, P. Jaszczuk, B. Juchniewicz, D. Łuczewska, L. Maluga, B. Siomkajło, K. Skwara, P. Wesołowski) oraz studentek i studentów II i III roku Wydziału Architektury Politechniki Wrocławskiej. Wystawa składała się z kilkudzięsięciu prac wykonanych w różnych technikach: przestrzennych (rzeźby, modele, meble), malarstwa, fotografii, kolaży, projektów graficznych.

\section{Introduction}

The year 1919, Weimar. It was here that the Bauhaus began its activity, an art and craft school which was established as a result of the merger of the Academy of Fine Arts and the School of Artistic Crafts. The year 2019, Wrocław. At the Faculty of Architecture of Wrocław University of Science and Technology, at the Department of Drawing, Painting and Sculpture, we began to celebrate the centenary of the Bauhaus, one of the most important and influential universities of the $20^{\text {th }}$ century. We do not build silent monuments, we want to return to the Bauhaus ideas from the perspective of our time and place, we want to get our students involved in joint activities. The final of the year-long project is an exhibition ${ }^{1}$ and a scientific conference.

In the times of building a new social order, the Bauhaus wanted to create a space suitable for the functioning of modern man. It was revolutionary and it was passionate about fundamental changes and it knew it was right. Andrzej Turowski in his artistic and political manifesto Art that arouses anxiety emphasizes the special relationship between the avant-garde and politics. If the revolutionary

1 The exhibition as part of the series "Space of architecture/space of art - After Bauhaus" was presented in the Museum of Architecture in Wrocław on 16.01-23.02.2020. The works of lecturers (H. Bujak, E. Górska, K. Jaklewicz, P. Jaszczuk, B. Juchniewicz, D. Łuczewska, L. Maluga, B. Siomkajło, K. Skwara, P. Wesołowski) as well as students of the second and third years of the Faculty of Architecture of Wrocław University of Science and Technology were presented. The exhibition consisted of several dozen works made in various techniques, i.e. spatial (sculptures, models, furniture), painting, photography, collages, and graphic designs. 


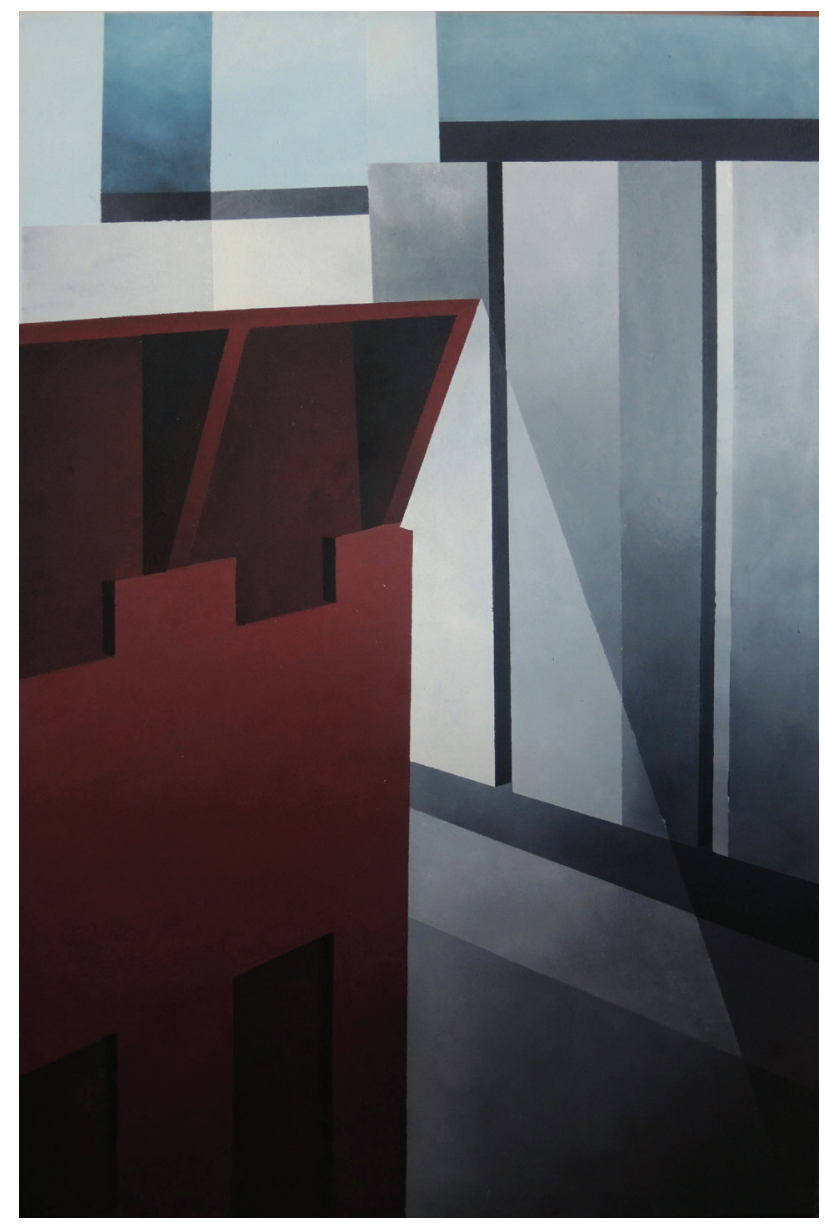

I1. 1. Gabriela Szczerba, Wrażenie bryty. Homage a Feininger (akryl, $70 \times 100 \mathrm{~cm}, 2019$ )

Fig. 1. Gabriela Szczerba, Impression of the body. Homage a Feininger (acrylic, $70 \times 100 \mathrm{~cm}, 2019$ )

Bauhausu przyrównać do motywacji twórców rosyjskiej awangardy, można uznać, że historie obu środowisk potoczyły się podobnie - w Rosji [...] pułapką okazała się wiara $w$ ideologie partyjnej wtadzy, która awangardy wcale nie pragnęła [1, s. 23], w Niemczech nazistowskie władze zamknęły ostatecznie Bauhaus w 1934 r., a dzieła twórców modernistycznych umieściły na liście „,sztuki zdegenerowanej”, co w konsekwencji oznaczało emigrację progresywnych artystów. Przywołuję relację sztuki i polityki, bo z perspektywy czasu interpretujemy sztukę jako wyraz estetycznych czy - jak w przypadku modernizmu - estetyczno-funkcjonalnych dążeń. Sztuka progresywna zawsze miała temperaturę polityczną, powinniśmy o tym pamiętać niezależnie od neutralizującego wpływu czasu².

2 Perspektywa zaangażowanej awangardy rosyjskiej lat 20. XX w. nie była władza, a rewolucja. Sztuka miała być ,skokiem ku wolności”, która rewolucja zapowiadała. [...] Whistorii kultury rosyjskiej państwa radzieckiego awangarda podejmujaca wyzwanie polityczne przegrała. Przegrała jej utopia społeczno-artystyczna $w$ zderzeniu z ideologia polityczna władzy sowieckiej, przegrało jej zaangażowanie z polityczna biurokracją komunizmu [...]. Przegrali tworzacy ją artyści. Pozostała jednak sztuka, której udało się odnaleźć w samej formie przykład artystycznej rewolucji, w odmienności kształtu - odwage zerwania z konwencja, w eksperymencie - projekt nowego. O przegranej awangardy przesądzaty aspirations of the Bauhaus are compared to the motivations of the founders of the Russian avant-garde, it can be concluded that the histories of both environments were similar - in Russia [...] it was a trap to believe in the ideology of one party power, which did not want the avant-garde at all [1, p. 23]. In Germany, the Nazi authorities finally closed the Bauhaus in 1934 and placed the works of modernist artists on the list of "degenerated art", which as a consequence meant the emigration of progressive artists. I refer to the relationship between art and politics because in retrospect we interpret art as an expression of aesthetic or - as in the case of modernism - aesthetic and functional aspirations. Progressive art has always had a political temperature and we ought to bear this in mind, regardless of the neutralizing influence of time ${ }^{2}$.

The Bauhaus's spectacular influence on contemporary architecture and design is beyond dispute. Among many outstanding lecturers in the school, I am particularly interested in one figure. Due to personal reasons. I was born in Trzebiatów (German: Treptow an der Rega) in 1979, i.e., forty-four years after Lyonel Feininger visited this area for the last time, which was then a popular summer holiday destination at the Ostsee, the Baltic Sea. I look at some archival photos from those years, which were issued in a series of black and white postcards - Regemunde (today Mrzeżyno), a small settlement before World War II at the mouth of the River Rega, welcoming up to 2,500 summer visitors a year. Hooded beach chairs regularly placed on the wide beach, fisherman's huts, fishing boats and flags with swastikas waving over the beach. After these flags appeared, the Feininger family never came to Mrzeżyno again.

In this article, I would like first of all to introduce the figure of Lyonel Feininger, point out his connections with today's Polish territories and the activities of the Trzebiatów Cultural Centre aimed at researching and popularizing the seaside oeuvre of this artist. In the background, I emphasise the relationship between art and politics, between art and history, that is, the relationships between those spheres that art tries to avoid, although they are inevitable ${ }^{3}$. The text is accompanied by the illustrations made in 2019 by female students - paintings from the

2 The perspective of the engaged Russian avant-garde of the $1920 \mathrm{~s}$ was not the government, but the revolution. Art was supposed to be a 'jump to freedom' announced by the revolution. [...] In the history of Russian culture of the Soviet State, the avant-garde undertaking the political challenge lost. Its socio-artistic utopia lost in clash with the political ideology of the Soviet government, its involvement lost with the political bureaucracy of communism [...]. The artists who created it lost. However, there remained art which managed to find an example of an artistic revolution in its very form, in a different shape - the courage to break with convention, in an experiment - a project of a new one. The defeat of the avant-garde in the Soviet Union, as in fascist Germany, was primarily caused by totalitarian political systems, under which culture could only exist as an instrument of reign. From this point of view, avant-garde art was always perceived as degenerated [1, p. 23].

3 The work is always in some situation, in some story, in which voice and silence meet a response. It is impossible to get out of this "even if we sat quietly and without a word, like stones, we would still act through our passivity" [...] - according to Andrzej Turowski, quoting Sartre [1, p. 22]. 
Spektakularny wpływ Bauhausu na współczesną architekturę i design jest bezsporny. Spośród wielu wybitnych pracowników szkoły szczególnie interesuje mnie jedna postać. Z przyczyn losowych. Urodziłam się w Trzebiatowie (niem. Treptow an der Rega) w 1979 r., czterdzieści cztery lata po tym, jak Lyonel Feininger po raz ostatni odwiedził te okolice, będące wówczas kierunkiem letnich wakacji nad Ostsee, Morzem Bałtyckim. Przeglądam archiwalne zdjęcia $\mathrm{z}$ tamtych lat, wydane w serii czarno-białych pocztówek - Regemunde (dziś Mrzeżyno), przed II wojną światową niewielka osada u ujścia rzeki Regi, przyjmująca do 2,5 tysiąca letników rocznie. Wiklinowe kosze regularnie rozmieszczone na szerokiej plaży, rybackie chaty, kutry i powiewające nad plażą flagi ze swastykami. Po pojawianiu się tych flag rodzina Feiningerów już nigdy nie przyjechała do Mrzeżyna.

W poniższym tekście chciałabym przede wszystkim przybliżyć postać Lyonela Feiningera, wskazać na jego związki z dzisiejszymi terenami Polski i działania Trzebiatowskiego Ośrodka Kultury mające na celu badanie i popularyzację nadmorskiej twórczości tego artysty. W tle zaznaczam relację między sztuką i polityką, między sztuką i historią, czyli relacje między tymi sferami, których sztuka próbuje uniknąć, choć są nieuniknione ${ }^{3}$. Tekst ilustrują prace wykonane w 2019 r. przez studentki - obrazy z cyklu „Homage a Feininger” prezentowane na wspomnianej wystawie w Muzeum Architektury (il. 1-4).

\section{Przestrzeń życia}

Lyonel Feininger urodził się 17 lipca 1871 r. w Nowym Jorku jako pierwsze dziecko niemieckiego wiolonczelisty Karla Feiningera i amerykańskiej piosenkarki niemieckiego pochodzenia Elizabeth Feininger. Dzieciństwo spędził w Nowym Jorku. Od najmłodszych lat przejawiał uzdolnienia muzyczne, konstruktorskie i plastyczne. W 1887 r. młody Lyonel pokazał 13 rysunków na swojej pierwszej szkolnej wystawie. W tym też roku wyjechał do Berlina i rozpoczął studia w Königliche Akademie w pracowni malarza Ernsta Hanckego. Jednocześnie rysował karykatury do tygodnika „Humoristische Blatter". Kolejny etap nauki to pobyt w jezuickim College St. Servais w belgijskim Liège. Oczarowanie historyczną zabudową Liège oraz pobliskiej Brukseli ujawni się z czasem w pracach opartych na motywach architektonicznych. Po powrocie do Berlina rozpoczął naukę w szkole artystycznej Karla Schlabitza, a po jej zamknięciu wrócił do Königliche Akademie. Feininger aktywnie uczestniczył w życiu niemieckiej awangardy - jego rysunki pokazywane były na corocznych wystawach Berlin Secession

\footnotetext{
w Zwiąku Radzieckim, podobnie jak w Niemczech faszystowskich, przede wszystkim totalitarne systemy polityczne, w ramach których kultura mogła istnieć jedynie jako narzędzie panowania. Z tego punktu widzenia sztuka awangardowa byta widziana zawsze jako zdegenerowana [1, s. 23].

3 Dzieło jest zawsze $w$ jakiejś sytuacji, $w$ jakiejś historii, $w$ których głos i milczenie napotykaja na oddźwięk. Niepodobna się z tego wywikłać „choćbyśmy siedzieli cicho $i$ bez słowa, jak kamienie, i tak działalibyśmy przez nasza bierność” [...] - zauważa Andrzej Turowski, cytując Sartre'a [1, s. 22]
}

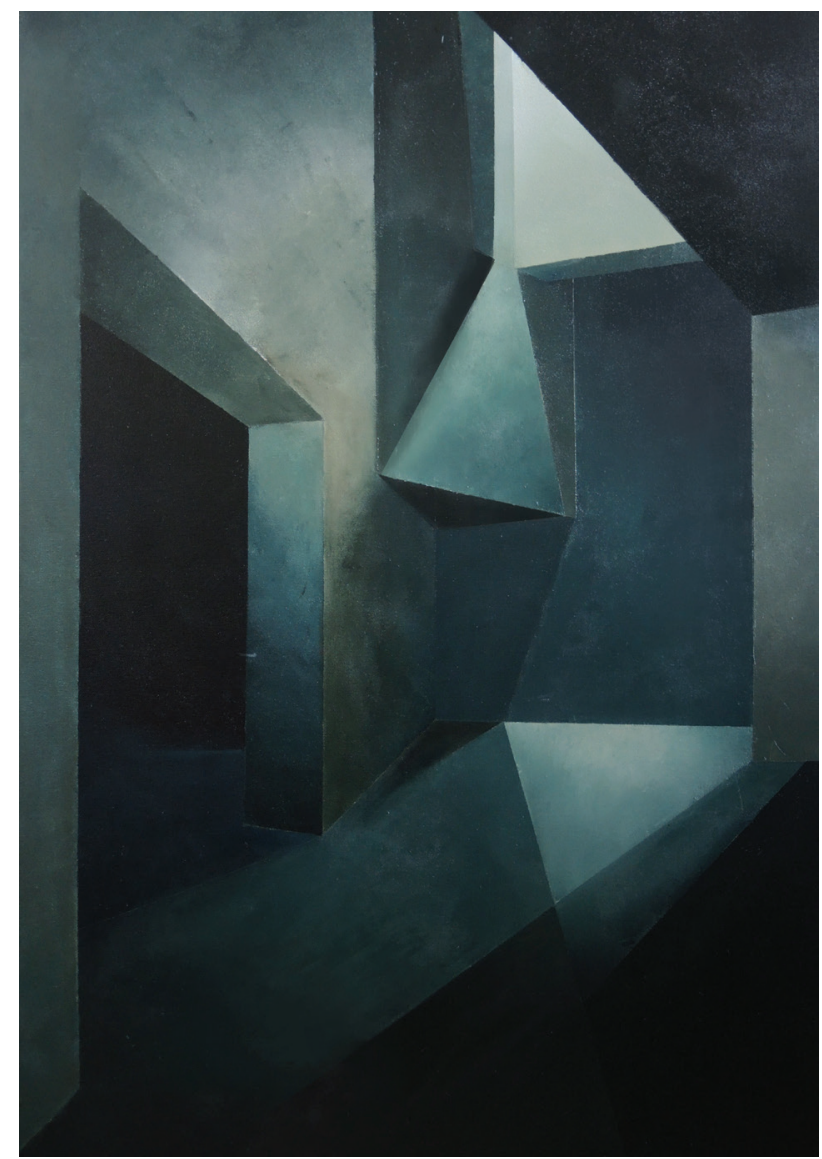

I1. 2. Olga Domalewska, Wrażenie bryty. Homage a Feininger (akryl, $70 \times 100 \mathrm{~cm}, 2019$ )

Fig. 2. Olga Domalewska, Impression of the body. Homage a Feininger (acrylic, $70 \times 100 \mathrm{~cm}, 2019$ )

series "Homage a Feininger", which were presented at the above-mentioned exhibition at the Museum of Architecture (Figs. 1-4).

\section{Living space}

Lyonel Feininger was born on July 17, 1871 in New York as the first child of Karl Feininger, a German cellist and Elizabeth Feininger, an American singer of German origin. He spent his childhood in New York. From an early age, he showed musical, constructive, and artistic talents. In 1887, young Lyonel showed 13 drawings at his first school exhibition. In the same year he went to Berlin and began studies at Königliche Akademie in the studio of painter Ernst Hancke. At the same time, he drew caricatures for "Humoristische Blatter" weekly. The next stage of study took place at St. Servais Jesuit College in Liège, Belgium. The enchantment with the historic buildings of Liège and nearby Brussels were revealed over time in works which were based on architectural motifs. After returning to Berlin, he began studies at Karl Schlabitz Art School, and after its closure he returned to Königliche Akademie. Feininger actively participated in the life of the German avant-garde - his drawings were shown at the annual exhibitions of the Berlin Secession (in 1901-1903) and Grosse Berliner Kunstausstellung. He was a member 


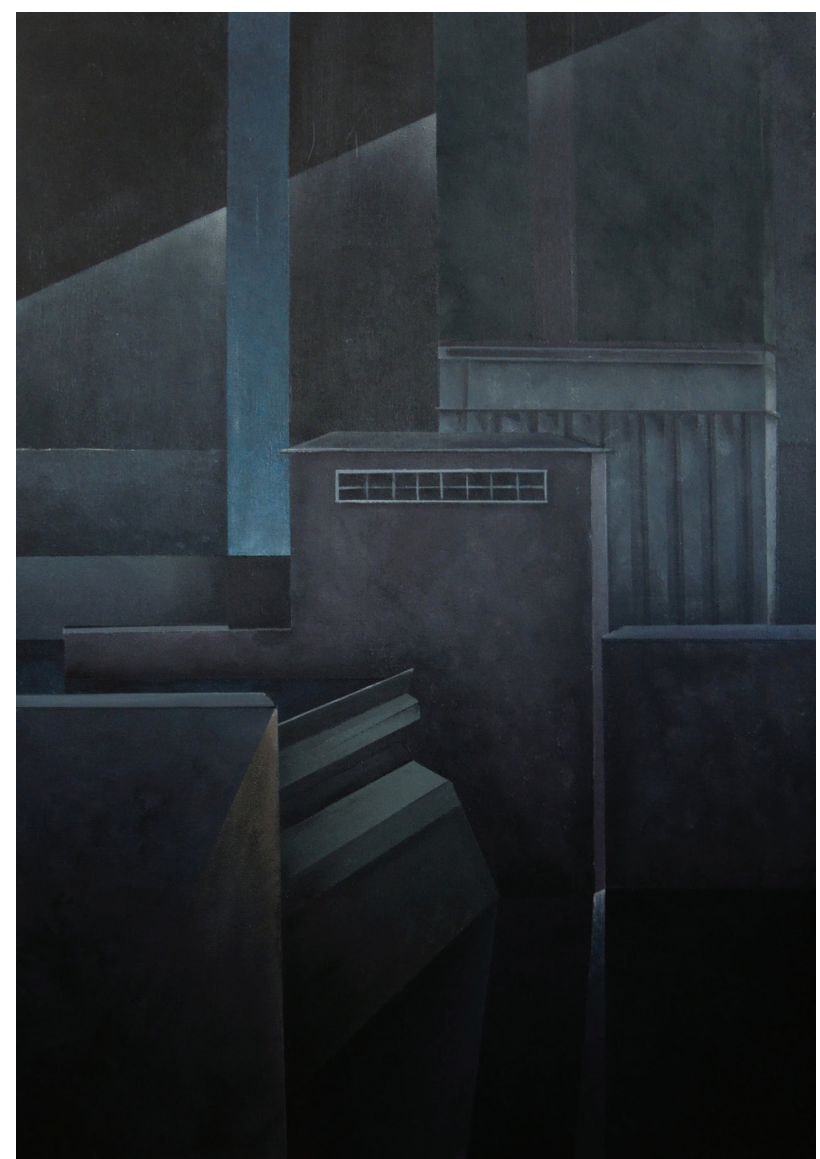

Il. 3. Katarzyna Jasińska, Wrażenie bryly. Homage a Feininger (akryl, $70 \times 100 \mathrm{~cm}, 2019$ )

Fig. 3. Katarzyna Jasińska, Impression of the body. Homage a Feininger (acrylic, $70 \times 100 \mathrm{~cm}, 2019$ )

(w latach 1901-1903) oraz Grosse Berliner Kunstausstellung. Był członkiem grupy ekspresjonistów Der Blaue Reiter, współpracował z Die Brucke [2, s. 126].

Wojnę spędził w Braunlage w górach Harz. Sytuacja materialna zmusiła go do zarzucenia malarstwa, jednak dostępność drewna pozwoliła na odkrycie techniki drzeworytu. To właśnie drzeworyt autorstwa Feiningera był umieszczony na okładce wydanego w 1919 r. manifestu Waltera Gropiusa. Feininger objął posadę profesora grafiki na nowo powstałej uczelni. Na terenie Bauhausu odnowił przyjaźń z Wassilym Kandinskim, Paulem Klee, Aleksiejem Jewlenskym - w 1924 r. założyli grupę Die Blauen Vier jako kontynuację Der Blaue Reiter. Poza działalnością pedagogiczną i wystawienniczą Feiningera pochłaniał okoliczny pejzaż. Rowerowe eskapady po okolicy zaowocowały szkicami wiejskich uliczek i kościołów. Motywy te rozwinięte zostały później w obrazach olejnych, jak choćby w cyklu przedstawiającym podweimarską wieś Gelmeroda z charakterystyczną strzelistą wieżą kościoła.

Sytuacja Feiningera, jak wielu mu współczesnych artystów, skomplikowała się w 1933 r., po dojściu nazistów do władzy. Za powód do emigracji wystarczyłby fakt żydowskiego pochodzenia jego żony Julii, ale nowa władza dotknęła też bezpośrednio samego artysty, zaliczając jego sztukę do kręgu zdegenerowanej i umieszczając 19 jego of expressionist group Der Blaue Reiter and collaborated with Die Brucke [2, p. 126].

He spent the war in Braunlage in the Harz Mountains. The material situation forced him to give up painting, but the availability of wood allowed him to discover the technique of woodcut. It was the woodcut by Feininger that appeared on the cover of Walter Gropius' manifesto published in 1919. Feininger took up the post of professor of graphics at the newly established university. In the Bauhaus, he renewed his friendship with Wassily Kandinski, Paul Klee, Alexei Jewlensky - in 1924 they founded Die Blauen Vier group as a continuation of Der Blaue Reiter. Apart from his teaching and exhibition activities, Feininger was fascinated with the surrounding landscape. Bicycle trips around the area resulted in sketches of rural streets and churches. These motifs were later developed in oil paintings, for example in the series depicting the village of Gelmeroda near Weimar with a characteristic soaring church tower.

Feininger's situation, like many of his contemporaries, became complicated in 1933, after the Nazis came to power. The fact that his wife Julia's was of Jewish origin would be enough as a reason to emigrate, but the new government also directly affected the artist himself, including his art in the degenerated circle and placing 19 of his works at the traveling exhibition of Degenerated Art (Entartete Kunst) ${ }^{4}$. Feininger, like most of the Bauhaus lecturers, emigrated to the United States. He arrived in New York in 1937.

Feininger's oeuvre can be divided into several areas. The first is the work of an illustrator. His drawings and caricatures were printed by German and American magazines such as "Harper's Round Table", "Harper's Young People”, "Humoristische Blätter", "Lustige Blätter”. Feininger was also the author of some of the earliest press comics. "The Chicago Sunday Tribune" printed full-page colour comics The Kin-der-Kids and Wee Willie Winkie's Word in 1906 and 1907 [4]. Another area, as it turned out later, which was connected with painting was modelling. Feininger passionately made models of ships and locomotives - due to the war, his design of a wooden train for the Munich toy factory was not implemented. He was also the author of valued photographs, but what constitutes the uniqueness of his artistic thought was most fully revealed in his painting.

Feininger's works are in private collections as well as in museums. The permanent exhibition of Feininger's works is in the Lyonel Feininger Galerie/Museum für grafische Künste in Quedlinburg (Germany), where the works from the collection of Dr. Hermann Klummp are presented. Other works are, inter alia, at Harvard Art Museum, Guggenheim Museum, and The Museum of Modern Art (MoMa). Three original drawings were loaned to

4 The Minister of Propaganda of the Third Reich, Joseph Goebbels, did not initially have a negative attitude to modern art, but influenced by Hitler, he chose a commission which divided art into "German" and "collapsed after 1910". "The right choice" (ironic title) was presented at the Great Exhibition of German Art, the artists of Entartete Kunst rebellious to authorities [3, p. 446]. 
prac na objazdowej wystawie Sztuki Zdegenerowanej (Entartete Kunst $)^{4}$. Feininger, tak jak większość wykładowców Bauhausu, wyemigrował do Stanów Zjednoczonych. Do Nowego Jorku przybył w 1937 r.

Twórczość Feiningera można podzielić na kilka obszarów. Pierwszy to praca ilustratora. Rysunki i karykatury jego autorstwa drukowały takie niemieckie i amerykańskie magazyny jak „Harper's Round Table”, „Harper's Young People”, „Humoristische Blätter”, „Lustige Blätter”. Feininger był też autorem jednych z najwcześniejszych prasowych komiksów. „Chicago Sudany Tribune” wydrukował w 1906 i 1907 r. całostronicowe, kolorowe komiksy The Kin-der-Kids i Wee Willie Winkie's Word [4]. Kolejny obszar, jak się później okaże, połączony $\mathrm{z}$ malarstwem to modelarstwo. Feininger z pasją wykonywał modele statków i lokomotyw - z powodu wojny nie został zrealizowany jego projekt drewnianego pociągu dla monachijskiej fabryki zabawek. Był także autorem cenionych fotografii, jednak to co stanowi o oryginalności jego myśli artystycznej, najpełniej objawiło się w malarstwie.

Prace Feiningera znajdują się w kolekcjach muzealnych i prywatnych. Stała wystawa prac Feiningera znajduje się w Lyonel Feininger Galerie / Museum für grafische Künste w Quedlinburgu (Niemcy), gdzie prezentowane są prace z kolekcji dr. Hermanna Klummpa. Inne prace znajdują się m.in. w Harvard Art Museum, Guggenheim Museum, The Museum of Modern Art (MoMa). Trzy oryginalne rysunki zostały wypożyczone Trzebiatowskiemu Ośrodkowi Kultury na czas nieokreślony i są tam prezentowane.

\section{Przestrzeń bryty}

W 1911 r. Feininger odbył przełomową dla jego twórczości podróż do Paryża, gdzie spotkał się z dziełami Pabla Picassa i Georges'a Braque'a. Zafascynowany kubizmem wprowadził jego elementy do swoich obrazów [2, s. 125]. Z nowego nurtu Feininger zaczerpnął rozbicie form na geometryczne figury. Kompozycje z tego okresu są dynamiczne, wręcz drapieżne. Formy budowane głównie $\mathrm{z}$ trójkątów i rombów wzmacniają ekspresyjny wyraz prac. Dynamika, miejscami przechodząca w gwałtowność, to efekt diagonalnych rytmów i zaburzenia równowagi brył. Feininger powtórzył kubistyczny motyw rowerzystów w Wyścigu rowerowym z 1912 r. czy malowany wcześniej przez Braque'a motyw drzew w Alei z 1915 r. Jednak głównym tematem jego prac była architektura i motywy marynistyczne. Styl Feiningera skrystalizował się ostatecznie pod wpływem środowiska Bauhausu. Układ płaszczyzn stał się klarowny, architektura wróciła do równowagi. Kubistyczna drapieżność przekształciła się w kontemplacyjną geometrię. Liczba elementów

\footnotetext{
${ }^{4}$ Minister propagandy III Rzeszy Joseph Goebbels początkowo nie był negatywnie nastawiony do sztuki nowoczesnej, jednak pod wpływem Hitlera dokonał wyboru komisji, która podzieliła sztukę na „niemiecką” oraz „upadłą po 1910”. „Słuszny wybór” prezentowano na Wielkiej Wystawie Sztuki Niemieckiej, artystów niepokornych wobec władzy na Entartete Kunst [3, s. 446].
}

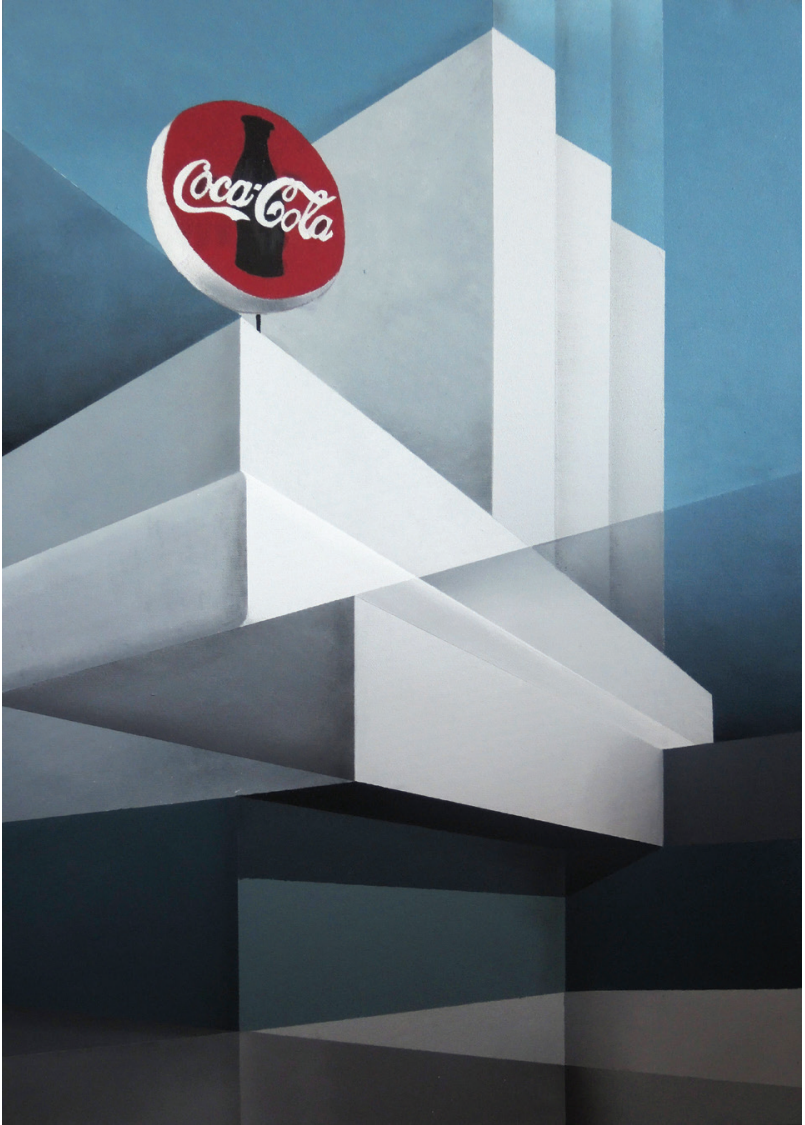

I1. 4. Kamila Boroch, Wrażenie bryly. Homage a Feininger (akryl, $70 \times 100 \mathrm{~cm}, 2019$ )

Fig. 4. Kamila Boroch, Impression of the body. Homage a Feininger (acrylic, $70 \times 100 \mathrm{~cm}, 2019$ )

the Trzebiatów Cultural Centre for an indefinite period and are presented there.

\section{Space of the body}

In 1911 Feininger made a trip to Paris, which was a breakthrough for his creative activity and it was where he met the works of Pablo Picasso and Georges Braque. Fascinated by cubism, he introduced its elements to his paintings [2, p. 125]. Feininger derived a division of forms into geometric figures from the new trend. The compositions from this period are dynamic, even rapacious. Forms which are constructed mainly of triangles and rhombuses enhance the expressive image of the works. Dynamics, which sometimes turns into violence, results from diagonal rhythms and imbalance of the bodies. Feininger repeated the Cubist motif of cyclists in The Bicycle Race from 1912 or the tree motif in The Avenue painted earlier by Braque in 1915. However, the main theme of his works was architecture and maritime motifs. Feininger's style finally crystallized under the influence of the Bauhaus milieu. The layout of planes became clear and architecture returned to balance. Cubistic rapaciousness turned into contemplative geometry. The number of geometric elements was significantly reduced, and calmer quadrilaterals appeared in the place of sharp triangles. Light, which 
geometrycznych uległa zdecydowanej redukcji, w miejscu ostrych trójkątów pojawiły się spokojniejsze czworoboki. Kluczowe dla atmosfery prac zaczęło być się światło, przez kubistów traktowane drugorzędnie. Obrazy stały się kontemplacyjne i analityczne.

Przemianę malarstwa Feiningera można zaobserwować w cyklu trzynastu obrazów (do dziś przetrwało dziesięć) przedstawiających motyw kościoła z Gelmerody, powstałych na przestrzeni ćwierćwiecza. Artysta odkrył tę podweimarską wieś jeszcze przed wyjazdem do Paryża, gdy odwiedzał swoją przyszłą żonę Julię studiującą w Weimarze. Później wracał do Gelmerody podczas pracy w Bauhausie.

Obraz Gelmeroda II z 1913 r. to połączenie ekspresjonizmu znanego z wczesnej twórczości Feiningera i wpływów kubistycznych. Ekspresja wyraża się przez kontrastowe zestawienie żółtego tła $\mathrm{z}$ czarną bryłą kościoła. Wpływ kubizmu to rozbicie zarówno tła, jak i samej bryły budynku na trójkątne pola. Odchylenie wieży kościelnej od pionu, powtórzone ukośnym układem drzewa dynamizują kompozycję i wprowadzają niepokój. W kolejnych odsłonach - Gelmeroda IV z 1915 r. i Gelmeroda VII z 1917 r. - wpływ kubizmu stał się jeszcze wyraźniejszy. Dynamiczne, zgeometryzowane kompozycje, z odchyloną od pionu osią obrazu tworzą gwałtowną i ostrą wizję kościoła. Przyglądając się uważnie, zaobserwujemy dwa elementy, które w tych obrazach są tylko szczegółami, ale w późniejszych dziełach zdominują klimat malarstwa Feiningera. W Gelmeroda $I V^{5}$ występuje ogólne światło zewnętrzne, ale w wieży kościoła artysta umieścił zielony otwór okienny, przez który wpada tajemnicze światło. Natomiast w Gelmeroda VII podobnie zagadkowym momentem jest wejście do kościoła. Kolejne z cyklu obrazy Gelmeroda VIII ${ }^{6}$, Gelmeroda IX z 1926 r. czy Gelmeroda XII ${ }^{7}$ z 1929 r. to zupełnie inny Feininger. Kompozycje uspokajają się, wracają linie równoległe i kąty proste. Istotnym elementem obrazu staje się światło. A jest to światło specyficzne, bo niepoddane rygorom logicznego kierunku padania. Dowolne płaszczyzny obrazu są rozświetlone od wewnątrz. Same dla siebie stanowią źródło światła i powierzchnię odbijającą. Bryły tracą ciężar, piony i poziomy porządkują kompozycje. Laserunkowo malowane płaszczyzny przenikają się, zacierając logikę brył. Wydaje się, że w tych obrazach mamy do czynienia nie tyle $\mathrm{z}$ namalowanymi bryłami, ile z namalowanym wrażeniem brył.

\section{Przestrzeń nadmorska}

Relacje między światłem, a szerzej - między naturą a człowiekiem (cywilizacją) jeszcze dokładniej widać w ,nadmorskiej” twórczości Feiningera.

W 1924 r. Lyonel Feininger odkrył położoną nad Morzem Bałtyckim wioskę rybacką Mrzeżyno (Regenmunde)

\footnotetext{
5 https://www.guggenheim.org/artwork/1220 [data dostępu: 3.06.2020]

6 https://whitney.org/collection/works/386 [data dostępu: 3.06.2020]

7 https://risdmuseum.org/art-design/collection/church-gelmeroda -xii-38059 [data dostępu: 3.06.2020].
}

was treated as secondary by cubists, began to be of key importance for the atmosphere of the works. The paintings became contemplative and analytical.

The transformation of Feininger's painting can be observed in a series of thirteen paintings (ten have survived to this day) depicting the theme of the church from Gelmeroda, which were created within a period of 25 years. The artist discovered this village near Weimar still before leaving for Paris, when he was visiting his future wife Julia who was studying in Weimar. He later returned to Gelmerody while working in the Bauhaus.

The painting Gelmeroda II from 1913 is a combination of expressionism known from Feininger's early creative activity and cubist influences. Expression is reflected by contrasting the yellow background with the black body of the church. The influence of cubism is the division of both the background and the body of the building into triangular fields. The tilt of the church tower from the vertical, which is repeated with a diagonal arrangement of trees, dynamizes the composition and introduces anxiety. In subsequent paintings - Gelmeroda IV from 1915 and Gelmeroda VII from 1917 - the influence of cubism became even more pronounced. Dynamic, geometrical compositions, with the axis of the image tilted from the vertical, create a violent and sharp vision of the church. Looking attentively, we will observe two elements which in these paintings are details only, but in later works they will dominate the atmosphere of Feininger's painting. There is general external light in Gelmeroda $I V^{5}$, but the artist placed a green window opening in the church tower through which a mysterious light got inside. However, in Gelmeroda VII, a similarly mysterious moment is the entrance to the church. The next paintings from the series Gelmeroda VIII ${ }^{6}$, Gelmeroda IX from 1926 or Gelmeroda XII from 1929 represent a completely different style of Feininger. Compositions become calmer, parallel lines and right angles return. Light becomes an essential element of the painting. And it is a specific light because it is not subject to the rigors of the logical direction of incidence. Any planes of the painting are illuminated from the inside. They constitute a source of light and a reflecting surface for themselves. The bodies lose weight, verticals and levels organize the compositions. The glazed surfaces interpenetrate, blurring the logic of the bodies. It seems that in these paintings we are dealing not so much with painted bodies, but with a painted impression of them.

\section{Seaside space}

The relationships between light, and more broadly - between nature and man (civilization), can be seen even more precisely in the "seaside" Feininger's works.

In 1924, Lyonel Feininger discovered the fishing village of Mrzeżyno (Regenmunde) at the Baltic Sea [2, p. 126]. Choosing this place for a summer stay, he planned

\footnotetext{
5 https://www.guggenheim.org/artwork/1220 [accessed: 3.06.2020].

6 https://whitney.org/collection/works/386 [accessed: 3.06.2020].

$7 \mathrm{https}$ ://risdmuseum.org/art-design/collection/church-gelmerodaxii-38059 [accessed: 3.06 .2020 ].
} 
[2, s. 126]. Wybierając to miejsce na letni pobyt, planował obserwować ruch statków kursujących między Świnoujściem a Heringsdorfem. Rzeczywistość zweryfikowała jego marzenia. Jak pisał, Nigdzie nie widać żadnego stat$k u$, sa one tak daleko, że tylko widać na horyzoncie ich dym z komina. Morze jest opuszczone i samotne, jakim do tej pory go nie widziałem (za: [2, s. 126]). W 1924 r. puste plaże Mrzeżyna, potargane lasy, rybackie chatki i kutry oczarowały Feiningera do tego stopnia, że każde wakacje aż do 1935 r. spędzał z rodziną właśnie tutaj. Niezapomniana podróż kolejka wąskotorowa do Mrzeży$n a$ - wspomina jego syn Lux - czy dzisiaj jeszcze można odbyć tę petna wrażeń podróż? Po drodze wystęuja wsie: Trzebusz, Roby. I wreszcie Mrzeżyno. Przyjemny chłodek, mokre ścieżki z piasku, specyficzny zapach morza i lasu. Jeszcze wiele lat później padało corocznie $w$ naszej rodzinie postanowienie - do Mrzeżyna nie pojedziemy już więcej, ale zawsze, każdego lata, podejmowaliśmy tę pielgrzymke (za: [2, s. 126]).

Nadmorski krajobraz inspirował Feiningera dwojako - artysta rozwinął i pogłębił swoje marynistyczne zainteresowania, ale także uległ nowej fascynacji: naturą. Podczas długich spacerów brzegiem morza Feininger obserwował różnorodność chmur, ich odbicia w tafli wody, zmieniające się światło. Poznał zmienne oblicze koloru morza - od stalowego chłodu gładkiej jak lustro powierzchni, przez ciepłą szarozieloną barwę ogrzanej wody, pomarańczowe refleksy zachodzącego słońca, po głęboki granat toni połyskujący srebrem wieczornego światła. Pisał: Wieczorem na plaży jest niespotykane niebo. Kolory widze w morzu - nie do opisania. Zachody słońca, których nie widziałem od mego dzieciństwa (za: [2, s. 127]). Metafizyczne doznania przeniósł na szkice i obrazy. Czternastego czerwca 1930 r. zanotował: [...] woda jest jak lustro, jasna, wysoka ściana chmur. Na horyzoncie samotny parowiec, a naprzeciw jego lustrzane odbicie. Dtugo zastanawiatem się, co to może być. Wreszcie maluję ten widok (za: [2, s. 127]).

Olśniony zjawiskami przyrody potrafił przenieść na płótno nie tylko ich wygląd, ale przede wszystkim klimat. W swoich nadmorskich obrazach uchwycił wyjątkowe relacje między ziemią, wodą i powietrzem. Specyfiką nadmorskiego krajobrazu są relacje natury do człowieka. Wobec bezkresu nieba i wody postać ludzka jest szczegółem - tak też uchwycił te relacje Feininger. Postaci ludzkie pojawiają się także w niektórych kompozycjach architektonicznych (np. Gelmeroda VIII i Gelmeroda IX) - tam niewielkie sylwetki kontrastują z wielkością kościoła. Na obrazie Chmury nad morzem z 1923 r. umieszczone w dolnej części kompozycji postaci są szczegółem, jednak centralna pozycja, w której się znajdują, sprawia, że ten szczegół porządkuje obraz, wprowadza równowagę i symetrię. Tytułowe chmury w niczym nie przypominają miękkich cumulusów - zgeometryzowane, oddzielone od błękitu nieba prostym cięciem wyglądają jak wspomniana w cytacie ściana. Równie intrygująco przedstawione zostało niebo w pracy Vogelwolke ${ }^{8}$ z 1926 r. Zbudowana

\footnotetext{
8 https://www.harvardartmuseums.org/collections/object/304376 ?position=1 [data dostępu: 3.06.2020].
}

to observe ships' courses between Świnoujście and Heringsdorf. Reality verified his dreams. As he wrote, no ships can be seen anywhere, they are so far away that only their smoke from the chimney can be seen on the horizon. The sea is deserted and lonely, like I have never seen it before (after: [2, p. 126]). In 1924, Feininger was so enchanted by empty beaches of Mrzeżyno, "dishevelled' forests, fishers" huts and fishing boats that he spent every vacation here with his family until 1935. An unforgettable journey by narrow-gauge railway to Mrzeżyno - recalls his son Lux - is it still possible to make this exciting journey today? On the way there are villages of Trzebusz and Roby. And finally Mrzeżyno. Pleasant coolness, wet sand paths, a specific smell of the sea and forest. Even many years later, every year our family made a decision - we would not go to Mrzeżyno anymore, but we always, every summer, undertook this pilgrimage (after: [2, p. 126]).

The seaside landscape inspired Feininger in two ways - the artist not only developed and deepened his maritime interests, but he also succumbed to a new fascination, namely nature. During long walks along the seashore, Feininger observed the variety of clouds, their reflections in the water surface, and the changing light. He discovered the changing face of the colour of the sea - from the steel cold of the mirror-smooth surface, through the warm grey-green colour of the heated water, orange reflections of the setting sun, to the deep navy blue depths shimmering with silver of the evening light. He wrote: In the evening on the beach, there is an unusual sky. I see colours in the sea-indescribable. Sunsets that I have not seen since my childhood (after: [2, p. 127]). He transferred his metaphysical experiences into sketches and pictures. On June 14, 1930, he noted: [...] water is like a mirror, a bright, high wall of clouds. A lonely steamer on the horizon, with a mirror image in front of it. I was wondering for a long time what it could be. Finally, I am painting this view (after: [2, p. 127]).

Enchanted by the phenomena of nature, he was able to transfer to canvas not only their appearance, but most of all the atmosphere. In his seaside paintings, he captured the unique relationship between land, water, and air. The relationship between nature and man is a specific feature of the seaside landscape. In the face of the vastness of the sky and water, the human figure is a detail - this is how Feininger captured these relations. Human figures also appear in some architectural compositions (e.g., Gelmeroda VIII and Gelmeroda $I X$ ) - there, small figures contrast with the size of the church. In the painting titled Clouds above the Sea from 1923, the figures placed in the lower part of the composition are a detail, but the central position in which they are placed makes this detail organize the painting, introduces balance and symmetry. The clouds in the title do not resemble soft cumulus clouds in any way - geometrized, separated from the blue of the sky by a simple cut, they look like the wall mentioned in the quotation. The sky was also intriguingly presented in the work Vogelwolke ${ }^{8}$ from

\footnotetext{
8 https://www.harvardartmuseums.org/collections/object/304376 ?position=1 [accessed: 3.06 .2020 ].
} 
z geometrycznych płaszczyzn świetlista chmura unosi się nad wodą, rozkładając skrzydła niczym ptak. Tajemnicza chmura zdaje się nie odbiciem, lecz źródłem światła - w jej blasku stoi postać. Umieszczona w dolnym rogu stanowi kontrapunkt dla niezwykłej chmury, a jednocześnie przez wspólne światło zespala się z nią.

Feininger był nie tylko wrażliwy na doznania zmysłowe, równie mocno pogłębiał swoje techniczno-konstruktorskie zainteresowania. Nad morzem miał ku temu doskonałą okazję. Letni dzień nie byt nic wart dla mego ojca, jeśli przynajmniej parę godzin nie mógt spędzić nad swoją deska kreślarska (za: [2, s. 127]) - relacjonował Lux Feininger, syn malarza. I dalej: Wielkim wydarzeniem każdej podróży do Mrzeżyna było puszczanie na wodzie modeli jachtów, które Lyonel Feininger budowat zima. Fotografie tych modeli postużyly później jako baza do obrazów i akwareli (za: [2, s. 127]). Podobnie jak szkice kutrów, eleganckich jachtów czy dużych frachtowców. Doświadczenia płynące $\mathrm{z}$ mistycznych doznań natury i miłość do statków zespoliły się w późniejszych pracach. Jachty, podobnie jak budowle, nie są już odzwierciedleniem realnych obiektów, jak to miało miejsce we wcześniejszych marynistycznych szkicach. Rozświetlone trójkąty żagli emanują mistycznym blaskiem, przenikają się z geometrycznymi płaszczyznami nieba i wody. Takie są Jachty z 1929 r. Precyzyjna myśl i ulotne wrażenia świetlne tworzą obraz zespalający emocje z rozumem - nie sposób oprzeć się takiemu odczytaniu tego obrazu. Równie frapujący jest namalowany w 1927 r. Regenklarheit. Na pozór spokojna kompozycja kryje w sobie napięcie podobne poprzedzającej sztorm niepokojącej ciszy. Kolorystyka płaszczyzny wody, bliższa kolorom ziemi, wskazuje, że nie o wizerunek pejzażu tu chodzi, a o subiektywne doznanie widoku. Błękit zazwyczaj przynależny niebu tu pojawił się na żaglach. Czy można zatem traktować owe $\mathrm{z}$ nieba stworzone żagle w sposób symboliczny? Czy jest to opisana przez Worringera geometria wyrażająca potrzeby religijne? [5, s. 11]. Sztuki Feiningera nie można określić mianem religijnej, nie można też nie zauważyć mistycznych cech jego obrazów. Bez względu na źródło światła - czy to wynikającego z natury, czy z symbolicznego Absolutu - Feininger traktuje światło podmiotowo. Nie tracąc nic ze swojej lekkości, otrzymuje ono od autora rodzaj cielesności. Dostrzegając te dwa komponenty, można przytoczyć wypowiedź Stefana Gierowskiego, artysty, dla którego światło było jednym z fundamentów twórczości. Zwracając uwagę na materialność światła w kontekście fizyczno-naukowym, dostrzegał także jego metafizyczny charakter. W rozmowie ze Zbigniewem Taranienko powiedział: [...] [światło i przestrzeń] to dwa konkretne elementy budowy obrazu, a równocześnie dwa pojęcia - bardzo szerokie i bogate $w$ treści. [...] Cała metafizyka zwiazana jest ze świattem. Ale jest ono ważne także w planie malarskim. Każdy kolor jest określany świattem w sposób absolutny... Tak jak pędzel, farba i płótno sa narzędziami pracy malarza, sa nimi także światto i przestrzeń. [...] Obecnie w moim wyobrażeniu taczę materię ze świattem, [...] bo materia ujawnia się poprzez światło $[6$, s. 65,66$]$. Podobne połączenie - światła i materii
1926. The luminous cloud, made of geometric planes, rises above water, spreading its wings like a bird. The mysterious cloud does not seem to be a reflection, but a source of light - a figure stands in its glow. Placed in the lower corner, it is a counterpoint to the unusual cloud, and at the same time, through the common light, it merges with it.

Feininger was not only sensitive to sensual experiences, but he also deepened his technical and constructive interests. He had a perfect opportunity to do so at the seaside. A summer day was worth nothing to my father, if he could not spend at least a few hours at his drawing board (after: [2, p. 127]) - reported Lux Feininger, the painter's son. And later: A great event of each trip to Mrzeżyno was the launching of yacht models on water, which Lyonel Feininger was building in winter. Photographs of these models later served as a basis for paintings and watercolours (after: [2, p. 127]). Similarly to the sketches of fishing boats, elegant yachts or large freighters. The experiences of mystical sensations of nature and the love for ships were combined in later works. Yachts, like buildings, no longer reflect real objects, as it was in the case of earlier maritime sketches. The illuminated triangles of the sails emanate with mystical glow, they interpenetrate with geometric planes of the sky and water. These are The Yachts from 1929. Precise thought and elusive light impressions create a picture which combines emotions with the mind - it is impossible to resist reading the picture in such a way. Equally striking is Regenklarheit which was painted in 1927. The seemingly calm composition hides a tension similar to the worrisome silence preceding the storm. The colours of the water plane, which are closer to the colours of soil, indicate that it is not about the image of the landscape that is at stake here, but a subjective experience of the view. The blue that usually is characteristic of the sky appeared on the sails here. Is it possible, then, to treat these sails made of heaven in a symbolic way? Is it the geometry described by Worringer which expresses religious needs? [5, p. 11]. Feininger's art cannot be called religious, but the mystical features of his paintings cannot be ignored. Regardless of the source of light - whether resulting from nature or symbolic Absolute - Feininger treats light subjectively. Without losing any of its lightness, it receives a kind of carnality from the author. Noticing these two components, we can quote a statement by Stefan Gierowski, an artist for whom light was one of the foundations of his oeuvre. Paying attention to the materiality of light in the physical and scientific contexts, he also noticed its metaphysical character. In an interview with Zbigniew Taranienko, he said: [...] [light and space] are two specific elements of the painting's creation, and at the same time two concepts - very broad and rich in content. [...] All metaphysics is connected with light. But it is also important in the painting plan. Each color is defined by light in an absolute way... Just like a brush, paint and canvas are the painter's working tools, so are light and space. [...] At present, in my mind, I combine matter with light [...] because matter is revealed through light $[6, \mathrm{pp} .65,66]$. A similar combination - light and matter - can be observed in Feininger's works. Thanks to geometry, paintings acquire 
- można zaobserwować w pracach Feiningera. Dzięki geometrii obrazy nabierają uniwersalnego charakteru bliskiego zarówno symbolicznym znaczeniom najprostszych figur znanych ze sztuki pierwotnej, jak i bardziej skomplikowanym właściwościom liczb i kształtów charakterystycznym dla poglądów starożytnych Greków. Dla Platona [...] poznanie geometryczne dotyczy tego, co istnieje wiecznie [5, s. 20], a pitagorejska tradycja w trójkącie widziała symbol podstawowy. Może dlatego trójkątne żagle u Feiningera to coś więcej niż kawałek płótna? Ich wyjątkowość kryje się zarówno w kształcie, jak i w nadrealnym rozświetleniu.

Spędzając nad morzem kolejne lata Feininger nie stronił od wypadów w głąb lądu. Powstało wiele szkiców i obrazów przedstawiających zabytki okolicznych miast. Trzebiatów jest bardzo pięknym, starym miastem, ma ogromnie wysoka wieżę, która wystaje ponad niskie, piętrowe domki (za: [2, s. 130]). Tak w pierwszym liście z Mrzeżyna z 28 czerwca 1924 r. Feininger opisał miasto leżące kilkanaście kilometrów przed Mrzeżynem.

Ulokowany na wzgórzu w zakolu rzeki Regi kościół widnieje na wielu rysunkach i akwarelach. Feininger szkicował go z wielu miejsc. Szkic z 22 czerwca 1925 r. przedstawia monumentalną bryłę górującą nad zabudową mieszkalną ${ }^{9}$, na rysunkach węglem z 1932 r. kościół jest na pierwszym planie. Feininger w ogóle dużo uwagi poświęcał wieżom. W większości jego architektonicznych kompozycji występują zarówno zwieńczone wieżami kościoły, jak i inne budowle strzelistego typu. W Trzebiatowie odkrył Basztę Kaszaną - wysoką, okrągłą wieżę - element dawnych murów obronnych miasta. Widnieje już na rysunkach ${ }^{10} \mathrm{z}$ pierwszej wizyty w mieście w 1924 r. W następnych latach powstały kolejne szkice, a w 1928 artysta namalował Basztę Kaszaną w charakterystycznym geoluministycznym stylu. Feininger studiował wąskie uliczki, szkicował widoki Trzebiatowa, na podstawie których wykonał późniejsze obrazy na płótnie. $\mathrm{Z}$ okolicznych budowli namalował jeszcze katedrę w Kamieniu Pomorskim, katedrę kołobrzeską, gryficką Basztę Prochową. Szczególnych inspiracji dostarczył mu kościół w Trzęsaczu. Do dziś potok turystów podąża tam ku wydmom, na których skraju ostała się ostatnia ściana gotyckiego kościółka. Resztę budowli na przestrzeni wieków pochłonęło morze. Feininger stworzył serię obrazów odwołujących się do tego symbolicznego miejsca, m.in. Ruiny nad morzem ${ }^{11}$ (Ruine am Meer) z 1930.

Rozstanie z Mrzeżynem było bolesne. Po 1933 r. wydmy zamieniły się w koszary. Powstała stacja wojsk powietrznych. Szerzył się antysemityzm. Ostatni pobyt - już bez żony Julii, której żydowskie pochodzenie uniemożliwiło urlop nad morzem - Feininger spędził z synem. Laurence i ja czuwamy przy najdroższym, teraz już umartym Mrzeżynie (za: [7, s. 159]) - pisał 13 września 1935 r.

\footnotetext{
9 https://www.harvardartmuseums.org/collections/object/187012 ?position=5 [data dostępu: 3.06 .2020 ].

10 https://www.harvardartmuseums.org/collections/object/186826 ?position=4 [data dostępu: 3.06 .2020 ].

11 https:/www.moma.org/collection/works/80044 [data dostępu: 3.06.2020]
}

a universal character close to both the symbolic meanings of the simplest figures known from primary art, and the more complicated properties of numbers and shapes typical of views of the ancient Greeks. For Plato [...], geometric cognition concerns what exists eternally [5, p. 20], and the Pythagorean tradition saw the basic symbol in the triangle. Maybe this is the reason why Feininger's triangular sails are more than just a piece of canvas? Their uniqueness lies both in the shape and in the surreal illumination.

Spending the next years at the seaside, Feininger did not avoid excursions inland. Many sketches and paintings showing monuments of the surrounding towns were created. Trzebiatów is a very beautiful old town, it has an enormously high tower which protrudes above the low two-storey houses (after: [2, p. 130]). This is how Feininger, in the first letter from Mrzeżyno of June 28, 1924, described the town situated several kilometers away from Mrzeżyno.

The church, which is located on a hill in the bend of the River Rega, is featured in many drawings and watercolours. Feininger sketched it from many places. The sketch from June 22, 1925 shows a monumental body towering over the residential buildings ${ }^{9}$, whereas in the charcoal drawings from 1932 the church is in the foreground. In general, Feininger paid a lot of attention to towers. Most of his architectural compositions feature both churches crowned with towers and other structures of a soaring type. In Trzebiatów he discovered Baszta Kaszana - a high round tower - an element of the old city walls. It is already visible in the drawings ${ }^{10}$ from his first visit to the city in 1924. In the following years, he made more sketches and in 1928 the artist painted Baszta Kaszana in a characteristic geoluminist style. Feininger studied the narrow streets, sketched views of Trzebiatów, on the basis of which he made later paintings on canvas. He painted the cathedral in Kamien Pomorski, the Kołobrzeg cathedral and Baszta Prochowa in Gryfice. The church in Trzęsacz provided him with special inspirations. To this day, crowds of tourists walk towards the dunes, on the edge of which the last wall of the Gothic church has remained. The rest of the structure was deluged by the sea over the centuries. Feininger created a series of paintings referring to this symbolic place, including Ruins by the Sea ${ }^{11}$ (Ruine am Meer) from 1930.

Leaving Mrzeżyno was painful. After 1933, the dunes turned into barracks. An air force station was established there. Anti-Semitism was spreading. The last holidays - without his wife Julia whose Jewish origin made it impossible to spend holidays at the seaside - Feininger spent with his son. Laurence and I keep watching our dearest, now deceased Mrzeżyno (after: [7, p. 159]) - he wrote on September 13, 1935 .

\footnotetext{
9 https://www.harvardartmuseums.org/collections/object/187012 ?position=5 [accessed 3.06.2020].

10 https://www.harvardartmuseums.org/collections/object/186826 ?position=4 [accessed: 3.06 .2020 ].

11 https://www.moma.org/collection/works/80044 [accessed: 3.06.2020]
} 


\section{Przestrzeń historii}

Po stu latach od powstania Bauhausu patrzymy na epokę początku XX w. jak na zamknięty rozdział modernistycznej rewolucji. Patrzymy na ten zryw i wiarę w „miasto, masę, maszynę" 12 , patrzymy z bagażem konsekwencji autorytarnej władzy i bezwzględnych systemów totalitarnych. Patrzymy ze świadomością wpływu rozwoju cywilizacyjnego na środowisko naturalne. Patrzymy z niedowierzaniem - czy jeszcze kiedyś sztuka będzie wierzyła tak bardzo we własną siłę oddziaływania? Gdy w 1898 r. Emil Zola wypowiedział historyczne „J'accuse!” (z fr. Oskarżam!) nie wiedział, że zapoczątkuje świadome uczestniczenie artystów i intelektualistów w życiu publicznym. Problem demokracji i republiki, z punktu widzenia artystów, byt tam zagadnieniem estetycznej i etycznej polityczności, czyli gotowości do interwencji publicznej w momentach nadużyć prawa i konfliktów społecznych [1, s. 14]. Zola sprzeciwił się i poniósł konsekwencje - wyrok za zniesławienie i emigracja. Polityka przesunęła geograficzne granice życia Zoli, tak jak przesunęła te granice twórcom Bauhausu. Ulubione miejsce wakacji i jedna $\mathrm{z}$ ważniejszych inspiracji stały się dla Feiningera nieosiągalną zagranicą. Jego pierwsze obrazy powstałe w Nowym Jorku odwołują się do wspomnień niemieckich miast i Morza Bałtyckiego. Artysta dużo wystawiał, zdobywając nagrody i popularność. Odszedł 13 stycznia $1956 \mathrm{r}$.

Feininger stworzył obraz Trzebiatowa, Mrzeżyna i okolic. Nie tylko obraz na płótnie - jego twórczość inspirowana tymi miejscami buduje symboliczny obraz miasta, tworzy jego wielowarstwową historię, przerzuca pomost między tym, co minęło, a tym, co jest. Mit miasta prowadzi mnie do twórczości Konstandinosa Kawafisa. Grzegorz Jankowicz pisze we wstępie do tomu Wierszy wszystkich, że [...] za sprawa poezji miasto, w którym się urodzit i spędzit większa część życia, uległo wywyższeniu i odrealnieniu, stowem: umitycznieniu $[9$, s. 5]. Kawafis pisał o Aleksandrii, [...] aż cała stała się uczuciem [9, s. 341]. Niewątpliwie Feininger obdarzył szerokie plaże i okoliczne średniowieczne miasta uczuciem. Geometrię tych uczuć komponował z wyczuciem i wrażliwością. Polityka siłą oderwała go od ulubionego letniska, do letniska przybyli nowi mieszkańcy, siłą oderwani od swoich mitycznych wsi i miasteczek. Wraz z przejęciem ziem, domostw, porcelany przejmujemy także dziedzictwo kulturowe miejsca - jego ochrona, poznanie i upowszechnianie stało się tematem badań Renaty Korek i działań Trzebiatowskiego Ośrodka Kultury. Po latach Feininger symbolicznie powrócił nad morze - na wniosek Dyrektorki TOK Renaty Korek z okazji 725-lecia Trzebiatowa lokalna galeria sztuk została nazwana „Galerią Feiningera”. Galeria mieści się w zabytkowym Pałacu nad Młynówką, obecnej siedzibie Trzebiatowskiego Ośrodka Kultury, wcześniej pełniącym funkcję zamku, klasztoru, książęcej rezydencji, siedziby urzędów. Poza zbiorem materiałów

12 Tytuł eseju Tadeusza Peipera opublikowanego w „Zwrotnicy” [8] w 1922 r. jako manifest artystyczny Awangardy Krakowskiej.

\section{Space of history}

One hundred years after the Bauhaus was founded, we look at the era of the beginning of the $20^{\text {th }}$ century as a closed chapter of the modernist revolution. We look at this impulse and belief in the "city, mass, machine" 12 , we look with a burden of the consequences of the authoritarian power and ruthless totalitarian systems. We look with the awareness of the impact of civilization development on the natural environment. We look with disbelief - will art ever believe so much in its own power of influence? When in 1898 Emil Zola uttered the historic "J'accuse!" (in French I accuse!) he did not know that he would initiate the conscious participation of artists and intellectuals in public life. From the artists' point of view, the problem of democracy and the republic there constituted the issue of aesthetic and ethical politics, that is, the readiness to public intervention at times of abuse of law and social conflicts [1, p. 14]. Zola objected and suffered the consequences - he was convicted for defamation and had to emigrate. Politics shifted the geographical boundaries of Zola's life, just as it shifted these boundaries to the founders of the Bauhaus. A favourite place of vacation abroad and one of the most important inspirations became unattainable for Feininger. His first paintings, which were created in New York, refer to memories of German cities and the Baltic Sea. The artist exhibited a lot, won awards and gained popularity. He died on January 13, 1956.

Feininger created the image of Trzebiatów, Mrzeżyno and the surrounding area. Not only a painting on canvas - his oeuvre, which was inspired by these places, creates a symbolic image of the town, its multi-layered history, bridges the gap between what has passed and what is now. The town myth leads me to the oeuvre of Konstandinos Kawafis. In the introduction to the volume of Poems of All, Grzegorz Jankowicz writes that [...] the town in which he was born and spent most of his life was exalted and made unreal thanks to poetry, in a word: mythicized [9, p. 5]. Kawafis wrote about Alexandria [...] until it all became a feeling [9, p. 341]. Undoubtedly, Feininger bestowed affection on the wide beaches and surrounding medieval towns. He composed the geometry of these feelings with intuition and sensitivity. Politics forced him to leave his favourite summer resort, new residents came to this summer resort, forcibly separated from their mythical villages and towns. Along with the takeover of lands, houses, and porcelain, we also take over the cultural heritage of the place - its protection, knowledge and dissemination became the subject of Renata Korek's research and activities of the Trzebiatów Cultural Centre. Years later, Feininger symbolically returned to the seaside - at the request of the TOK Director Renata Korek, on the occasion of the $725^{\text {th }}$ anniversary of Trzebiatów, the local art gallery was called the "Feininger Gallery". The gallery is located in the historic Palace by Młynówka, the present seat of the Trzebiatów Cultural Centre, which previously performed

12 The title of Tadeusz Peiper's essay published in "Zwrotnica" [8] in 1922 as an artistic manifesto of the Cracow Avant-garde. 
źródłowych i organizacją wystaw TOK prowadzi programy edukacyjno-badawcze związane z działalnością Feiningera, na nowo osadzając jego postać i twórczość w Trzebiatowie i okolicach ${ }^{13}$.

13 Wśród działań można wymienić: Międzynarodowe Spotkania Artystyczne - Trzebiatów 2019 zorganizowane we współpracy z Uniwersytetem Artystycznym w Poznaniu, łączące twórczość współczesnych artystów z dziedzictwem L. Feiningera, publikacje i wystąpienia dr Renaty Korek w ramach organizowanych przez TOK seminariów naukowych: „Trzebiatów - historia i kultura 2000”, „Trzebiatów - spotkania pomorskie 2005", gromadzenie i udostępnianie w czytelni publikacji dotyczących L. Feiningera. the function of a castle, monastery, ducal residence, and seat of offices. Apart from the collection of source materials and the organization of exhibitions, TOK carries out educational and research programs which are connected with Feininger's activity, re-embedding his character and oeuvre in Trzebiatów and in the surroundings ${ }^{13}$.

Translated by Bogusław Setkowicz

13 Activities include: International Art Meetings - Trzebiatów 2019 organized in cooperation with the University of Arts in Poznań, which combine creative activities of contemporary artists with the heritage of L. Feininger, publications and speeches by Dr. Renata Korek as part of the scientific seminars organized by TOK: "Trzebiatów - history and culture 2000", "Trzebiatów - Pomorskie meetings 2005", collecting and making available in the reading room publications about L. Feininger

\section{Bibliografia/References}

[1] Turowski A., Sztuka, która wznieca niepokój, Instytut Wydawniczy Książka i Prasa, Warszawa 2012.

[2] Korek R., Lyonel Feininger malarz Mrzeżyna i Trzebiatowa, [w:] W. Lysiak (red.), Trzebiatów - historia i kultura, Poznań 2000, 125-132.

[3] Longerich P., Goebbels P., Apostol diabła, Prószyński i S-ka, Warszawa 2014.

[4] https://en.wikipedia.org/wiki/Lyonel_Feininger[accessed: 25.03.2020].

[5] Sztabiński G., Dlaczego geometria? Problemy współczesnej sztuki geometrycznej, Wydawnictwo Uniwersytetu Łódzkiego, Łódź 2004.
[6] Taranienko Z., Rozmowy o malarstwie, PIW, Warszawa 1987.

[7] Korek R., Korek T., Ptasia chmura. O podróżach Lyonela Feiningera do Mrzeżyna i okolic w latach 1924-1935, [w:] A. Bartczak, M. Witek, Europejskie Dni Dziedzictwa 2011. Kamienie milowe: materiały opracowane z okazji obchodów Europejskich Dni Dziedzictwa 2011 w województwie zachodniopomorskim, Biuro Dokumentacji Zabytków, Szczecin 2011, 147-160.

[8] Peiper T., Miasto. Masa. Maszyna, „Zwrotnica” 1920, nr 2, 23-31.

[9] Kawafis K., Wiersze wszystkie, Austeria, Kraków-Budapeszt-Syrakuzy 2019

\section{Streszczenie}

Z okazji odchodów 100-lecia powstania szkoły Bauhaus na Wydziale Architektury Politechniki Wrocławskiej zrealizowany został projekt naukowo-dydaktyczny zainspirowany twórczością wykładowców Bauhausu oraz metodyką nauczania praktykowaną przez tę uczelnię. Jednym z założycieli i wykładowców Bauhausu był Lyonel Feininger - grafik, ilustrator, malarz, konstruktor. Artysta ten przez kilkanaście lat spędzał letnie wakacje w dzisiejszym Mrzeżynie k. Trzebiatowa (woj. zachodniopomorskie). Feininger uwiecznił na szkicach i płótnach wiele zabytków, widoków miast, pejzaży, które obecnie znajdują się w granicach Polski. Niniejszy artykuł traktuje zarówno o życiu Feiningera w kontekście politycznych zmian, jakie dokonały się w latach 30. XX w., o podróżach nad Bałtyk, jak i o oryginalnym języku artystycznym. W szczególności zwraca uwagę na tematy architektoniczne, które są główną osią malarskich i rysunkowych studiów Feiningera. Oryginalny sposób malowania architektury jest na trwałe wpisany w historię sztuki współczesnej. Autorka przybliża także działania Trzebiatowskiego Ośrodka Kultury, który obecnie jest w Polsce najbardziej prężnym ośrodkiem popularyzującym dziedzictwo sztuki Feiningera.

Slowa kluczowe: Lyonel Feininger, Bauhaus, sztuka, architektura

\section{Abstract}

At the Faculty of Architecture of Wrocław University of Science and Technology, on the occasion of the $100^{\text {th }}$ anniversary of the Bauhaus School foundation, a research and teaching project, which was inspired by creative activities of the Bauhaus lecturers and the teaching methodology practiced by this university, was implemented. One of the founders and lecturers of the Bauhaus was Lyonel Feininger - a graphic artist, illustrator, painter, and constructor. The artist spent his summer vacation in today's Mrzeżyno near Trzebiatów several times (West Pomeranian Voivodeship). Feininger immortalized many monuments, town views, and landscapes that are now within the borders of Poland in his sketches and on canvas. This article is about Feininger's life in the context of the political changes that took place in the 1930s, about travelling to the Baltic Sea, and about a unique artistic language. The author draws special attention to architectural themes which constitute the main axis of Feininger's painting and drawing studies. The unique way of painting architecture is permanently fixed in the history of contemporary art. It also presents activities of the Trzebiatów Cultural Centre which is currently the most dynamic centre in Poland popularizing the heritage of Feininger's art.

Key words: Lyonel Feininger, Bauhaus, art, architecture 


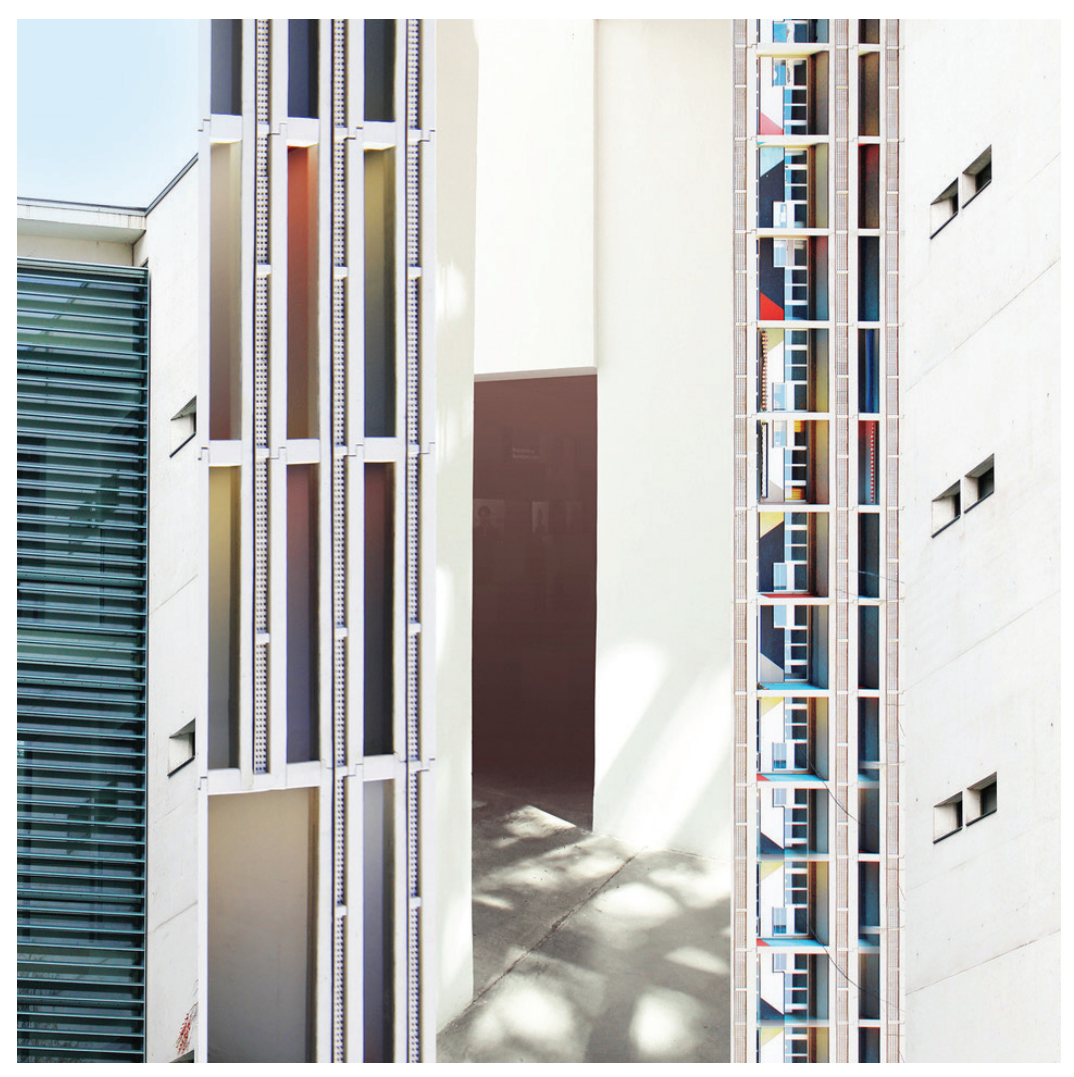

